\title{
Francesco Robortello's Rhetoric. On the Orator and his Arguments
}

\begin{abstract}
This paper deals with the conception of rhetoric of one of the most prominent Renaissance scholars, Francesco Robortello, and focuses in particular on his vernacular manuscript entitled Dell'oratore, probably his final statement on the topic, the transcription of which is included in the appendix. The study of the manuscript will be integrated with the examination of Robortello's Latin published works on rhetoric, that is De rhetorica facultate (1548) and De artificio dicendi (1567), as well as of some of his schemes in printed and manuscript form.
\end{abstract}

Keywords: Francesco Robortello, Rhetoric, Orator, Induction, Example, Aristotelianism

\section{Robortello and the Renaissance Vernacular RHETORIC}

\section{$\mathrm{T}$}

he name of Francesco Robortello (1516-1567) is usually associated with his activity of philologist and historian and the success of his In Aristotelis poeticam explicationes and De arte, sive ratione corrigendi antiquorum libros disputatio, both published in Florence in 1548, and both marking a new era in literary criticism. ${ }^{1}$

This research has been possible thanks to the ERC Starting Grant 2013, n. 335949 "Aristotle in the Italian Vernacular: Rethinking Renaissance and Early-Modern Intellectual History (c. 1400-c. 1650)".

${ }^{1}$ On Robortello cf. G.G. Liruti, Notizie delle vite ed opere scritte da' letterati del Friuli (Venezia: Fenzo, 1762), vol. 2, 413-483; B. Weinberg, "Robortello on the Poetics," in

Rhetorica, Vol. XXXIV, Issue 3, pp. 243-267. ISSN: 0734-8584, electronic ISSN: 1533-8541. (c) 2016 by The International Society for the History of Rhetoric. All rights reserved. Please direct all requests for permission to photocopy or reproduce article content through the University of California Press's Reprints and Permissions web page, http:/ / www.ucpress.edu/journals.php?p=reprints. DOI: 10.1525/rh.2016.34.3.243. 
In this paper I want to focus on a neglected aspect of Robortello's work, his conception of rhetoric, paying close attention in particular to his hitherto unstudied vernacular manuscript, Dell'oratore. I shall integrate the analysis of the manuscript with the study of Robortello's published Latin works on rhetoric, the De rhetorica facultate (1548) and the De artificio dicendi $\left(1560,{ }^{2} 1567\right),{ }^{2}$ and some of his schemes in

R.S. Crane et al., Critics and Criticism. Ancient and Modern (Chicago: The University of Chicago Press, 1952), 319-48; C. Diano, "Francesco Robortello interprete della catarsi," in Aristotelismo padovano e filosofia aristotelica (Firenze: Sansoni, 1960), 71-9; C. Diano, "Euripide auteur de la catharsis tragique," Numen 2 (1961): 117-41; B. Weinberg, A History of Literary Criticism in the Italian Renaissance (Chicago: Chicago University Press, 1961), vol. 1, 66 f and 388f; A. Carlini, "L'attività filologica di Francesco Robortello," Atti dell'Accademia di scienze lettere e arti di Udine 7 (1966-1969): 5-36; C. Diano, "La catarsi tragica," in Saggezze e poetiche degli antichi (Vicenza: Neri Pozza, 1968): 215-69; F. Donadi, "La catarsi storica secondo Robortello," Atti e memorie dell'Accademia patavina di Scienze Lettere ed Arti 82 (1969-1970): 63-9; F. Donadi, “Un inedito del Robortello: La Praefatio in Tacitum," Atti e memorie dell'Accademia patavina di Scienze Lettere ed Arti 82 (1969-1970): 299-321; G. Cotroneo, I trattatisti dell'ars historica (Napoli: Giannini, 1971), 121-68; E.E. Ryan, "Robortello and Maggi on Aristotle's Theory of Catharsis," Rinascimento 22 (1982): 263-73; A. Carlini, "Robortello editore di Eschilo," Annali della Scuola Normale di Pisa. Classe di Lettere e Filosofia 19 (1989): 313-22; M.J. Vega Ramos, La formación de la teoría de la comedia: Francesco Robortello (Cáceres: Servicio de Publicaciones de la Universidad de Extremadura, 1997); M. Venier, "Belloni, Robortello ed Egnazio: Nuovi e vecchi documenti su una contesa umanistica," Metodi e Ricerche 17 (1998): 51-66; S. Cappello, "Francesco Robortello e la sua opera nella cultura francese," in I rapporti dei friulani con l'Italia e con l'Europa nell'epoca veneta (Padova: Cleup, 2000), 117-46; F. Donadi, "Francesco Robortello da Udine," Lexis. Poetica, retorica e comunicazione nella tradizione classica 19 (2001): 79-91; D. Blocker, "Élucider et équivoquer: Francesco Robortello (ré)invente la catharsis," Le Cahiers $d u$ Centre de Recherches Historiques 33 (2004), 2-24; B. Zlobec Del Vecchio, "Talia divino dum fundit Sontius ore. Nota in margine a un carme di Francesco Robortello," Incontri triestini di filologia classica 6 (2006-2007): 121-39; K. Vanek, Ars corrigendi in der frühen Neuzeit. Studien zur Geschichte der Textkritik (Berlin-New York: De Gruyter, 2007), 15-51; S. Cappello, "Robortello, Francesco," in Nuovo Liruti. Dizionario biografico dei Friulani. II. L'età veneta, edited by C. Scalon, C. Griggio e U. Rozzo (Udine: Forum Editrice, 2009), 2151-57; M.C. Angioni, "L'Orestea nell'edizione di Robortello da Udine: alcuni casi di metafora e griphos," İtaca. Quaderns Catalans de Cultura Clàssica 27 (2011): 111-31; M.Venier, "Francesco Robortello: Discorso sull'arte ovvero sul metodo di correggere gli autori antichi," Ecdotica 9 (2012): 183-218; E. Garavelli, “Un frammento di Francesco Robortello: Del traslare d'una lingua in l'altra," in Studi di Italianistica nordica (Roma: Aracne, 2014): 287-305; S. Cappello, "L'editio princeps ritrovata del De artificio dicendi (1560) di Francesco Robortello," in Dal Friuli alle Americhe. Studi di amici e allievi udinesi per Silvana Serafin, edited by A. Ferraro (Udine: Editrice Universitaria, 2015), 133-148; M. Sgarbi, "Francesco Robortello on Topics," Viator 47 (2016), 365-388.

${ }^{2}$ The existence of the 1560 edition of the De artificio dicendi was unknown prior to 2014. Discovered by Cappello in the Biblioteca Civica di Udine (signature 7.B.8.25), this is the only surviving evidence of this first printed edition, and remains to this day uncatalogued in inventories both in Italy and internationally. I therefore take 
printed and manuscript form. As we shall see, Robortello's conception of rhetoric is both exceptional and innovative because he conceives of it as a tool for popularising knowledge, in other words for making even the most complex forms of knowledge available to a wider audience. The inferences deployed by the rhetorician to achieve this aim, in Robortello's view, are fundamentally different from those used by the logician and the dialectician, who are in a position to explicate with a greater degree of clarity the contents of knowledge. Robortello's task is thus to seek a new definition for classical inferences and to reposition the discipline within the framework of a new system of knowledge. The goal of rhetoric is the transmission of knowledge; therefore in Robortello's view the idea that rhetoric's function is to deceive or beguile the populace, rather than to serve as a tool for training people to the civic life, no longer holds. Hence the originality of Robortello's position within the context of Renaissance rhetoric.

What I aim to demonstrate by means of this inductive micro-historical approach is that research focusing on minor traces in the manuscripts and low-profile figures such as Robortello often reveals aspects of the Renaissance movement of vernacular rhetoric in Italy during the second half of the sixteenth century that are highly original. As Peter Mack has shown in his excellent latest work, A History of Renaissance Rhetoric 1380-1620, the history of rhetoric in the Renaissance is more fragmented and variegated than might be supposed, straying beyond the rigid confines of Aristotelianism and Ciceronianism within which it has traditionally been constrained. ${ }^{3}$ Robortello's evident aim in

the opportunity here to amend what I wrote in my previous paper, "Francesco Robortello on Topics," which was written, reviewed, accepted and sent to print before Cappello's discovery was published. In that article, I raised the question of whether there existed, at least in the author's mind, an alternative compilation of the De artificio dicendi to the one that was actually printed in 1567. I went on to suggest that the book published in 1567 might have been compiled posthumously, given its disjointedness, a characteristic attributable to a printer rather than to the author - a theory now supported, or at least not ruled out, by Cappello himself. My dating for the Discorso places it at the same time as, or later than, certain parts of the De artificio dicendi, which at that time I believed to have been first printed in 1567. I also asserted that the manuscripts held in the Biblioteca Nazionale di Napoli were notes associated with the De artificio dicendi. The latter remains a valid hypothesis, as does the dating of the Discorso at the same time as or later than certain parts of the De artificio dicendi, but no longer may it be ascribed to the latest period, as a greater lapse of time is needed. Also valid is the content analysis of the work. Cf. Cappello, "L'editio princeps ritrovata del De artificio dicendi (1560) di Francesco Robortello," 147.

${ }^{3}$ On Aristotle's rhetoric in the Renaissance cf. L.D. Green, The Reception of Aristotle's Rhetoric in the Renaissance, in Peripatetic Rhetoric After Aristotle: Rutgers University Studies in Classical Humanities (Oxford-New Brunswick NJ: Transaction Publishers, 1994), 320-348. On rhetorical Ciceronianism cf. R. Sabbadini, Storia del ciceronianismo 
following in Aristotle and Cicero's footsteps is to seek a third way that is completely new and can provide a valid alternative to those of his two antecedents, a conception in other words in which rhetoric is viewed as an essential tool in the acquisition of knowledge.

A large number of rhetorical manuals were written in the vernacular and circulated during the Renaissance in a wide range of institutional contexts such as universities, courts, academies, churches etc. ${ }^{4}$ Peter Mack has recently shown that a total of 436 editions of 100 vernacular textbooks on rhetoric were published between 1472 and 1620. Italy alone produced thirty rhetorical texts in 129 editions over the same period. ${ }^{5}$ These numbers refer only to the printed editions of vernacular rhetorics, but thanks to the Warwick project on Vernacular Aristotelianism in Renaissance Italy, c. 1400-c. 1650, we now know that many vernacular works are in manuscript form. To date, 19 manuscripts have been counted. The reason is that in general vernacular textbooks of rhetoric played no role in formal education, since grammar-school and university education was normally aimed at literary competence in Latin, ${ }^{6}$ and indeed if we look closely at Italian vernacular rhetoric manuals, we see that they were mainly conceived within the intellectual context of the newly emerging sixteenth-century academies, where rhetoric underwent profound changes and mutations. ${ }^{7}$ No longer merely the art of deploying techniques in public speaking with the aim of swaying an audience, rhetoric had come to play an increasingly central role in the construction of the model citizen and courtier that was to give voice to the humanistic ideal. Rhetoric thus

e di altre questioni letterarie nell'età della rinascenza (Torino: Loescher, 1885); J. Seigel, Rhetoric and Philosophy in Renaissance Humanism (Princeton: Princeton University Press, 1968); V. Cox, Ciceronian Rhetorical Theory in the Volgare: A Fourteenth-Century Text and its Fifteenth-Century Readers in Rhetoric and Renewal in the Latin West 11001544 (Turnhout: Brepols, 2003), 201-225; V. Cox, Ciceronian Rhetoric in Late Medieval Italy: The Latin and Vernacular Tradition, in The Rhetoric of Cicero in its Medieval and Early Renaissance Commentary Tradition, edited by V. Cox - J.O. Ward (Leiden-Boston. Brill, 2006), 109-143; K.M. Fredborg, Ciceronian Rhetoric and Dialectic, in The Rhetoric of Cicero in its Medieval and Early Renaissance Commentary Tradition, edited by V. Cox J.O. Ward (Leiden-Boston. Brill, 2006), 165-192; J. Monfasani, The Ciceronian Controversy, in The Cambridge History of Literary Criticism: Volume III. The Renaissance, edited by G. Norton (Cambridge: Cambridge University Press, 2008), 395-401.

${ }^{4}$ Cf. S.J. Milner, "Le sottili cose non si possono bene aprire in volgare: Vernacular Oratory and the Transmission of Classical Rhetorical Theory in the Late Medieval Italian Communes," Italian Studies 2 (2009), 221-244.

${ }^{5}$ Cf. P. Mack, A History of Renaissance Rhetoric, 1380-1620 (Oxford: Oxford University Press, 2011), 282-283.

${ }^{6}$ Cf. Ibid., 282.

${ }^{7}$ Cf. I.F. McNeely, "The Renaissance Academies between Science and the Humanities," Configurations 3 (2009), 248, 257. 
became an essential element in civilised conversation, letter writing and discourses aimed at targeted circles of individuals, such as in the courts or the academies, hence the proliferation in this period of rhetorical textbooks. Impressive though the number of Italian editions may have been, however, these vernacular rhetorics were generally either adaptations of pre-existing Latin works or works of little didactic value within the context of the teaching of rhetoric - in most cases, in fact, nothing more than comments or philosophical remarks on Cicero's works. By the turn of the sixteenth century, Italian rhetorical manuals were for the most part involved in the debates around the imitation of Latin eloquence and were concerned specifically with the possibility of transferring formal rhetorical arguments and prose-rhythm from Latin to the vernacular. ${ }^{8}$

Italy's champion for this approach was without doubt Pietro Bembo (1470-1547). Bembo's project to develop a theory of vernacular language was coloured by his Ciceronianism, which highlighted the elegance of the Latin models as a canon for interpreting literature, albeit not as a new creative force in the language. Bembo identified a pressing need for the vernacular to be transformed in light of the perfection of the Latin language, ${ }^{9}$ but in so doing he formulated no theories regarding its stylistic autonomy; indeed, his great innovation consisted in his refusal to adopt spoken Tuscan as a literary language. That the focus of his interests was written or literary language, not spoken language, and that this was the reason why he could champion archaic Florentine from the 1300s (especially Petrarch and Boccaccio) as a language of culture, is clear from his writings. Bembo had moreover adopted a precise theoretical position: only fourteenth-century Italian vernacular, immune as it was to the vagaries of time, was capable of fostering the historical recognition of the maturity of the Italian vernacular language, a recognition that Bembo himself reinforced with the development of a vernacular rhetoric based on the principles of classical rhetoric in the second book of his Prose.

The keenest of his contemporary observers soon realised the nature of the flaw in Bembo's proposal, and raised a more universal question about the expressive needs of the vernacular language. Readers of the Prose took this text as a manifesto advocating the possibility of developing an elegant vernacular that was in fact free from Latin canons.

${ }^{8}$ Cf. M.L. McLaughlin, Literary Imitation in the Italian Renaissance: The Theory and Practice of Literary Imitation in Italy from Dante to Bembo (Oxford: Clarendon Press, 1995).

${ }^{9}$ Cf. C. Dionisotti, Scritti sul Bembo (Turin: Einaudi, 2002), 211. 
The dissolution of the classical stylistic edifice is particularly evident in Sperone Speroni's Dialogo della retorica (1542), which established a sharp distinction between the rhetorical, eloquent vernacular of literary genres such as poetry and oratory, and an ordinary vernacular, which was useful for philosophical and scientific prose. Rhetorical vernacular language was therefore concerned mainly with civil philosophy, while common vernacular language was employed in speculative philosophy. Speroni furthermore included the discussion of Ciceronian rhetoric within in a broader context of Aristotelian rhetoric and its arguments. ${ }^{10}$ This particular trait of Italian vernacular treatises of the mid-sixteenth-century affects also Robortello's conception of rhetoric: Cicero continues to be the model, but he is assessed and discussed according to Aristotelian patterns. These rhetorical works were more concerned with philological discussions on classical rhetoric than with teaching rhetorical precepts, and, as we shall see, Robortello's work on rhetoric reflects some of these ideas in a very original way.

\section{Schematizing Rhetoric}

In their attempt to "Aristotelise" rhetoric, Robortello's two published Latin rhetorical works exemplify this mode of interpretation. De rhetorica facultate was published in 1548 with other treatises concerning the historiographic method, Roman history and poetry. It is mainly a collection of remarks, annotations and comments to Cicero's De inventione originated by Robortello's teaching when he was in Pisa in 1547. It is a work of scarce interest for the history of rhetoric, since it is concerned primarily with comparing the various conceptions of rhetoric in ancient authors such as Plato, Aristotle, Demosthenes, Cicero, Hermogenes, Alexander of Aphrodisias, giving examples with long quotations from Greek texts without any personal or original interpretation. The general view expressed in this work is that rhetoric is essential for practical purposes, politics in particular, an idea that is developed on the strength of the teachings of the ancient authors. In

\footnotetext{
${ }^{10}$ Cf. V. Vianello, "Res e verba nel Dialogo della Retorica di Sperone Speroni," Atti dell'Istituto Veneto di Scienze, Lettere ed Arti 138 (1979-1980): 231-53; J.L. Fournel, "La rhétorique vagabonde et le portrait de la vérité dans trois dialogues de Sperone Speroni," in Discours littéraires et pratiques politiques (Paris: Publications de la Sorbonne, 1987), 11-59; R. Girardi, "Ercole e il Granchio, figure della retorica speroniana," Giornale storico della Letteratura Italiana 167 (1990), 396-411; M. Sgarbi, The Italian Mind. Vernacular Logic in Renaissance Italy (1540-1551) (Leiden: Brill, 2014).
} 


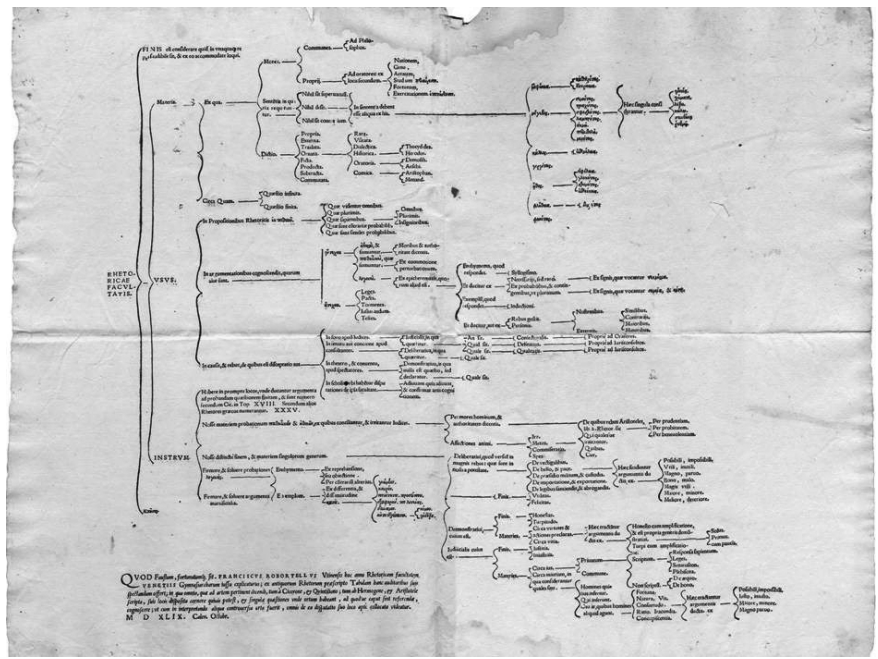

Robortello's Scheme

his later writings, as we shall see, this conception will be partially revised.

It is clear from the success of his lectures and the envy he aroused among his colleagues that Robortello's teachings on rhetoric enjoyed a certain notoriety among his students. He taught Greek and Latin rhetoric and eloquence in Lucca (1537/38-1543), Pisa (1543-1549), Venice (1549-1552), Padua (1552-1557), Bologna (1557-1561) and again in Padua (1561-1567). ${ }^{11}$ Robortello's innovativeness in teaching rhetoric is testified by the scheme of his first Venetian course held in 1549, and now preserved at the Museo Correr $(=\mathrm{BMCVe})$ in Venice in the folder Donà dalle Rose 447, folder 29.

Unlike many other Renaissance authors like Peter Ramus, ${ }^{12}$ for whom graphs and trees were simply an illustration of the doctrines set out in the body of the text, Robortello used diagrams to produce new knowledge. The order and arrangement of the diagrams was anything but a-systematic, impressionistic or in-homogenous; far from being mere mnemonic devices, their function was to reflect in some way the structure of the mind and the disposition of knowledge, in order for the generation of each cognition to be made absolutely clear.

\footnotetext{
${ }^{11} \mathrm{Cf}$. Liruti, Notizie delle vite ed opere scritte da' letterati del Friuli, 424-425, 436.

${ }^{12} \mathrm{Cf}$. W.J. Ong, Ramus, Method, and the Decay of Dialogue: From the Art of Discourse to the Art of Reason (Chicago: University of Chicago Press, 1983), 279; L.D. Green, Aristotle's Rhetoric Made Methodical, in Autour de Ramus: Texte, théorie, commentaire (Quebec: Nuits Blanches, 1997), 135-173.
} 
The need for this in Robortello's approach became particularly urgent in the fields of logic, dialectics and rhetoric, where it was customary to proceed by division or the presentation of the various topical places. Contrary to the numerous and varied experiments in dialectical and rhetorical classification carried out in the sixteenth century by those whose purpose was to reorganise Ciceronian rhetoric, Boethius' Topics and Agricola's dialectics, Robortello's work of schematisation was genuinely philosophical in its aim of ordering knowledge according to how it is produced, hence the importance of seeing how the points of the diagrams are connected and understanding the nature of the connections. The learning of dialectics and rhetoric is thus made simpler, a fact which is made clear if we examine the unedited Discorso dell'origine, numero, ordine et methodo delli luoghi topici, which is contained in Donà dalle Rose 447, folder 22 (ff. 1r-4v). ${ }^{13}$ Robortello faults Agricola's Topics and rhetoric for providing no real derivation or deduction of topical places capable of producing solid knowledge. All topical places appear to be grouped in a highly heterogeneous and non-systematic fashion, making it impossible to infer correctly from one place to the other. For Robortello, this shortcoming in Agricola's method stands in the way of real understanding through the diagram of the process of production of knowledge, in other words of how one place derives from another - an essential factor, in Robortello's view, which constitutes the very purpose of schematising knowledge. Only by making clear the connections between the various parts of knowledge is it possible to transform a heterogeneous aggregate of ideas into a real system of knowledge.

Diagrams, schemes, trees are thus not only a way of organising knowledge but must also reflect the processes of the mind in subdividing given problems and in generating possible solutions. Following the path outlined in the text, one does not only learn and remember the logical path followed by the author, but can also understand how knowledge is constructed and what are its basic building-blocks. It is clear that Robortello's concern was not only with the order and arrangement of knowledge, but also with its method of inquiry and acquisition, two aspects which will come to play a crucial role in philosophical discussions during the second half of the sixteenth century. ${ }^{14}$

\footnotetext{
${ }^{13}$ For a brief discussion of the manuscript cf. L. Bolzoni, The Gallery of Memory. Literary and Iconographic Models in the Age of the Printing Press (Toronto: Toronto University Press, 2001), 24-27. For a discussion of its content and a diplomatic transcription of the manuscript cf. M. Sgarbi, "Francesco Robortello on Topics," 365-388.

${ }^{14}$ Cf. N.W. Gilbert, Renaissance Concepts of Method (New York-London: Columbia University Press, 1960).
} 
With these new techniques for visualising knowledge, which will be exploited in the following years by many other rhetoricians up to the first decades of the seventeenth century with Bartholomäus Keckermann, Robortello opened up new horizons for rhetoric, as well as also for any other kind of discipline.

Robortello's idea of a scheme in connection with rhetoric is made particularly evident in the bottom-left corner of the diagram, where he explicitly states that

In hope of a successful result, Francesco Robortello from Udine - who, by order of the scholastic authorities, will teach a course on rhetoric in Venice this year based on the ancient rhetoricians - offers this table to his listeners for their perusal of all things that have to do with the art of speech - from Cicero to Quintilian, Hermogenes, or Aristotle which have been positioned in such a way that anyone can consult it, and thus can know the origin of every question and the heading to which one must refer. In this way, every time a controversy arises in interpretation, all that can be disputed about it will be readily identifiable in its place. ${ }^{15}$

This tree not only shows in nuce Robortello's conception of rhetoric, but also makes two fundamental things clear. First, that anyone can consult and understand it; secondly, that this scheme generates knowledge beyond being a valid aid to memorisation. ${ }^{16}$ The secret of Robortello's new and efficient method in teaching rhetoric consists in the fact that students were clearly able to see the network of relations, deductions, and derivations that unite one particular place with the others. The scheme clearly shows that the goal of rhetoric is to consider the persuasive and how to express it in an adequate way. Also interesting is Robortello's view of the use of rhetoric for knowing things, an interest that remains constant throughout his rhetorical writings. Robortello explicitly shows that rhetoric is useful in knowing things that pertain exclusively to civil philosophy. Rhetoric teaches the ethical precepts, how the passions move the soul, and how it can be employed during trials to judge, in the senate to deliberate, in the theatre to perform, or in the school to dispute. No original conception of rhetoric is presented, given the concise nature of the diagram, but in all likelihood he is following classical rhetoric, the subject-matter of the course. As we shall see, however, that eloquence is functional only in

\footnotetext{
${ }^{15}$ Emphasis are mine. Translated by Lina Bolzoni in Bolzoni, The Gallery of Memory, 25-26.

${ }^{16} \mathrm{Cf}$. Bolzoni, The Gallery of Memory. Literary and Iconographic Models in the Age of the Printing Press, 23-34.
} 
certain particular cases that concern the investigation of human actions, as opposed to the humanistic conception of rhetoric according to which rhetoric must be applied to all areas of research, is an idea Robortello held throughout the entire course of his life.

\section{Latin Rhetoric}

A more fruitful set of ideas may be found in the De artificio dicendi. ${ }^{17}$ The work, dedicated to Giovan Battista Campeggi, who is known also, and with good reason, as the "Christian Cicero,"18 showcases Robortello's new conception of rhetoric in which the focus is primarily on oratory. He is highly critical of contemporary rhetoricians trained by erudite and eloquent schoolteachers for whom rhetoric served solely for the embellishment of discourse, for persuasion and delusion, while in some glorious past they had been taught by the philosophers themselves for the express purpose of disseminating knowledge. This criticism reflects the generally held position on the teaching of rhetoric in the Italian education-system: at school-level, rhetoric was taught mainly through letter-writing and the study of one of the classical Latin companions to rhetoric, Cicero in particular, and in fact Italian teachers of rhetoric contributed nothing new to the subject, making only oblique reference to ways of approaching and embellishing a public discourse, or studying the ancient rhetoricians. ${ }^{19}$

Robortello, on the other hand, viewed rhetoric as a useful device for making the content of knowledge, in particular philosophy, more comprehensible and relevant to a wider public. Although the comprehensibility of philosophical discourse may sometimes come at the expense of accuracy in the portrayal of the true state of things, this is not equivalent to deceiving or peddling erroneous or simplified forms of knowledge: rather it means offering a form of knowledge that is available for the edification of all kinds of people, enabling them to acquire a more detailed knowledge. Rhetoric was thus seen to be essential in education and teaching for introducing everyone to the knowledge of things. That part of rhetoric which makes knowledge

\footnotetext{
${ }^{17}$ Cf. Liruti, Noizie delle vite ed opere scritte da' letterati del Friuli, vol. 2, p. 421.

${ }^{18} \mathrm{Cf}$. N. Aksamija, "Architecture and Poetry in the Making of a Christian Cicero: Giovanni Battista Campeggi's Tuscolano and the Literary Culture of the Villa in Counter-Reformation Bologna", I Tatti Studies 13 (2011), 133-43. Robortello has a long-lasting relationship with Campeggi, and already in 1559 dedicated to him the De vita, et victu populi romani (Benacci: Bologna, 1559).

${ }^{19}$ Mack, A History of Renaissance Rhetoric, 1380-1620, 164.
} 
popular, especially philosophy, is, in Robortello's view, oratory. Unlike philosophical and poetical discourse, oratorical discourse must have a certain degree of eloquence, because its task is to clarify knowledge for a wider audience and to give the opportunity to judge "concretely" the truth or the falsity of what has been said. ${ }^{20}$ In the chapter "Quomodo sermo philosophicus ad popularem et oratorium redigi possit", contained in the final unnumbered pages of the De artificio dicendi, and in the unedited work entitled "Regula deducendi sermonem philosophicum ad oratorium" contained in the manuscript Napoli, Biblioteca Nazionale (=BNN), V D $45,{ }^{21}$ Robortello presents four ways of making oratorical discourse philosophical, in other words making a difficult philosophical text more accessible to a wider range of listeners and readers: the first is to make an abstract notion more concrete, which is possible by means of the rhetorical inference of the example; the second is to transform a universal concept into a particular concept, for instance when the orator deals not with happiness according to its definition, but with the happy man; ${ }^{22}$ the third is to speak of philosophical concepts by means of metaphors; the fourth is to make a philosophical concept as clear as possible by using an abundance of words and phrases. A philosopher should not overdo the use of words and metaphors, which may further obfuscate the discourse, but the orator can use this technique to explain repeatedly and more effectively notions that are not completely clear to the populace. ${ }^{23}$ Rhetoric for Robortello is thus not a means of embellishing knowledge and making it more effective, but a tool for reaching a wider audience. In this way, Robortello elaborates a new conception of rhetoric which does not essentially imply wisdom as the humanists wanted, but is necessary when one wishes to disseminate knowledge to a wider public, targeting various layers of society. Robortello thus reconciles the anti-rhetorical movement of vernacular Aristotelianism, supported for instance by Speroni, with a humanistic fetishism for eloquence, by according it an important pedagogical role.

This conception is further developed in the work entitled Dell'oratore, which is contained in the BMCVe, ms. Donà dalle Rose 447, folder 28, and which has so far failed to spark any scholarly interest

\footnotetext{
${ }^{20}$ F. Robortello, De artificio dicendi (Bologna: Benati, 1567), 9r-v.

${ }^{21}$ For a description of the manuscript cf. P.O. Kristeller, Iter Italicum. A Finding List of Uncatalogued or Incompletely Catalogued Humanistic Manuscripts of the Renaissance in Italian and other Libraries Volume 1. Italy. Agrigento to Novara (Leiden: Brill, 1963), 416.

${ }^{22} \mathrm{BNN}, \mathrm{V}$ D $45, \mathrm{f} .70 \mathrm{r}$.

${ }^{23}$ BNN, V D 45, f. 70v.
} 
whatsoever. ${ }^{24}$ The manuscript seems to be datable prior to the original publication of the De artificio dicendi, since Robortello explicitly refers to it as a work in progress: "I will nonetheless be brief, reserving myself to address this dispute more fully in Latin." ${ }^{25}$ Unlike in his other works, in which he limited himself to setting out in sometimes original ways the positions of Aristotle, Cicero and Boethius, Robortello here presents his own personal conception of rhetoric, positioning himself in one of the hottest debates in sixteenth-century vernacular philosophy and distancing himself from both Aristotle and Cicero. The work is written in the form of a letter to an unknown recipient, and aims to answer two fundamental questions: 1) what is the role of the orator? 2) what are his arguments?

\section{The Orator}

The first question in particular is rephrased by Robortello to ask why oratory employs the imperfect enthymeme rather than the perfect syllogism of the logicians. The enthymeme in Aristotelian tradition was the rhetorical syllogism par excellence, the logical inference in other words that deduced "from verisimilitude and signs" ( $\xi \xi \varepsilon i x o ́ \tau \omega \nu$ xai $\sigma \eta \mu \varepsilon i(\omega v)$, building arguments upon premises that were not entirely certain, be it in the data they presented or the logical connections between them, and were thus of little value in the true apodictic demonstration, while the perfect syllogism arrived at conclusions through apodictic logical inferences. Later, with Cicero and Boethius, the enthymeme came to designate elliptical syllogisms in which one of the two premises was implied, as in "you are a man, therefore you are mortal," where the most important premise of all, "all men are mortal," is implied. Given their pithiness and efficacy, such syllogisms came to play a crucial role in classical oratory. This form of reasoning, in which, as in "omnes proditores sunt puniendi, ergo Aeschynes est puniendus," one of the two premises is omitted, is precisely what enthymeme meant for Robortello as well. He contended that none of the ancient rhetoricians were able to explain why oratory has always preferred the enthymeme to perfect syllogism, a fact which only makes finding the answer to the conundrum all the more cogent. The core of

\footnotetext{
${ }^{24}$ The work was catalogued for the first time in Catalogo dei codici che componevano l'archivio dei nobili conti Donà dalle Rose, ora presso il Museo Civico e Raccolta Correr, BMCVe, ms. Donà dalle Rose 7, f. 433.

${ }^{25}$ Cf. infra, p. 261.
} 
Robortello's answer, originating in his reading of the first book of Aristotle's Rhetoric, is that the "orator has to deal with rough audiences ignorant of sciences." ${ }^{26}$ Unlike the learned man of who reflects on everything through the intellect by means of universals, ignorant people are short-sighted and capable of understanding only particulars. Universals are indeed hard to understand, while particulars are more comprehensible for the "ignorant, and rough, that is popular man," but since the sciences consists of universal terms, ignorant people that cannot abstract from the particular to the universal cannot acquire scientific knowledge. Thus, according to Robortello, the role of the orator is to provide the ignorant audience with the proper tools for acquiring as much knowledge as possible through particulars. The task of the orator is therefore to deal with particulars without any consideration for universals, reason for which Robortello states that the orator arranges the matter of his reasoning in the form of "darii" syllogisms, not "barbara" syllogisms, as required by science. The "darii" syllogism proceeds from two premises, one universal, the other particular, arriving at a particular conclusion, while the "barbara" syllogism consists only of universal propositions which are not understandable by the populace. Genuine oratorical and popular reasoning should therefore be only in the form of the "darii" syllogism. The question may be raised of how the first universal proposition in the "darii" syllogism can be understood by the populace if the populace understands only particulars. Robortello gives two answers. First of all, common, rough people will understand the universal premises in relation to the second particular premises and the particular conclusion. Secondly, Robortello states that universal premises are usually left out of the enthymeme, as in the case of "Aeschynes est proditor, ergo est puniendus," and in this way the reasoning is easily understandable. But Robortello also distinguishes among various universals, and states that the oratorical universal is more comprehensible than the physical universal, or the universal of other sciences. The reason is quite simple for Robortello. Oratorical universals deal with the common and ordinary actions of human beings, which are well-known and understandable by all. Scientific or physical universals, on the other hand, are for specialists alone, being well beyond the reach of the populace. Once again, Robortello relies for his opinion upon Aristotle, who, in his Rhetoric, expressed the "very beautiful" idea that the subject-matter of the orator is all that is not concerned with scientific things, or written things, or things that can be the subject

\footnotetext{
${ }^{26}$ Cf. infra, p. 261.
} 
of science or can be written in the future. This idea leads to two very important conclusions.

The activity of an orator is mainly oral in the sense that it concerns the possibility of transmitting knowledge orally and not necessarily by the written word, which on the contrary seems necessary for all the other sciences. The subject-matter of the orator seems to be concerned only with what can be treated in moral philosophy and politics, that is human actions, not with all the other speculative sciences. Consequently, an orator can only popularise philosophical discourses that deal with moral philosophy, politics, law, etc., which explains why Robortello, in the chapter "Quomodo sermo philosophicus ad popularem et oratorium redigi possit," gives examples of how to popularise philosophy only in respect of ethics and civil philosophy, not other sciences. But this also means that common people can be taught only in practical disciplines dealing with particulars, not in sciences that inquire into universals. There is thus a sharp distinction for Robortello between moral philosophy for all and speculative philosophy, or science properly speaking, which is for the elite alone. As a matter of fact, Robortello restricts his conception of the popularisation of knowledge by identifying the domain of rhetoric strictly with civil philosophy. In so doing, he is following a characteristic conception of various Aristotelians such as Sperone Speroni, who maintained the idea that rhetoric was useful only for civil philosophy and literary purposes. He does point out, however, that one can argue that scientists employ enthymemes too, because they do not usually reason following complete syllogisms with all the premises. This is possible, Robortello states, because it is customary also for scientists to understand universal things even when one of the premises is lacking. Not even in his physical or astronomical works, notes Robortello, does Aristotle employ a complete syllogism. This amounts to a reduction of the language of science proper to a common or more popular scientific language, but without inhibiting the demonstrative force of the reasoning, since if in science some premise is lacking, this is because the scientist already implies it as being true.

Moreover, Robortello explains that the oratorical enthymeme is in "darii" form, not "barbara," because it is grounded in the rhetorical inference of the example, which is always particular. Syllogism, on the contrary, is based not on example, but induction.

\section{Rhetorical Arguments}

The distinction between induction and example gives Robortello the opportunity to tackle the second major question of his writing, in 
which he develops an original position that departs from Aristotle's doctrines. Robortello is not openly concerned with past opinions that seek to assess this difference, but rather he prefers to state "briefly what I estimate to be true in this subject ... without being moved by the authority of any writer." Robortello believes that the various opinions on this distinction were misled by the similarity between the two forms of reasoning. He gives a typically confusing case in which the distinction seems blurred. For instance, the inference "Peisistratus, Timoleon, Euridemus used their bodyguards to become tyrants, therefore all tyrants used their bodyguards" seems to be an example taken from history, a list of events that actually happened. ${ }^{27}$ But if we consider the same inference more in general in the form " $\mathrm{A}, \mathrm{B}, \mathrm{C}$ used $\mathrm{X}$ to obtain $Y$, therefore every $Y$ is obtained by $X$," then this seems to be more like an induction. So what is the real difference? This is something that must be explained and that past logicians and rhetoricians have failed to recognise.

For Robortello, the difference between example and induction relies essentially and exclusively upon subject-matter. Example is constituted only by private and public action collected in the histories, while induction is an inference from natural or artificial things. Example and induction therefore do not differ by form. In Aristotle, on the other hand, example is viewed as a particular considered as a universal for some of its particular characteristics, for instance Ulysses is the example of astuteness, while induction from particulars generates a real universal, thus in seeing Thales, Socrates, and Plato, the mind generates the universal concept of the human being, and here it rests.

Nothing similar exists in Robortello: he disagrees with Aristotle, outlining three rules for distinguishing example from induction. The first rule establishes that proceeding from particular to particular is no doubt identifiable with the Aristotelian inference of example. The second rule states that sometimes examples can proceed from some particulars to a particular. The third rule consists in proceeding from some particulars to a universal; it can be induction, as for Aristotle, but only if the particulars are natural or artificial things, otherwise, if they are human actions, the inference will remain an example. Therefore, according to Robortello, unlike Aristotle, an example can be universal if it is derived from many particulars which have to do with human actions, not by chance actions are those things that the philosopher

\footnotetext{
${ }^{27}$ On Robortello's use of example cf. C. Vasoli, Francesco Patrizi da Cherso (Roma: Bulzoni, 1989), 25-90; C. Vasoli, "Il modello teorico", in La storiografia umanistica (Messina: Sicania, 1992), 24-31.
} 
can popularise through oratorical discourse. Robortello adds that sometimes example concerns natural and artificial things, but in this case is properly called similitude.

So how can Robortello reconcile his view with that of Aristotle, whom he holds in "the greatest reverence"? Robortello explains that Aristotle himself seems to suggest his interpretation in the second book of the Rhetoric, where he groups the "locus ab inductione" with the case "Archilochus, Chios, and Homer were honoured, therefore all wise men are honoured" among the oratorical inferences. In Robortello's perspective this is not an induction, as Aristotle says, but an example, because it deals with human actions. Yet, he argues, in the second book of the Rhetoric Aristotle never mentions example as inference, but seems rather to support the view that "sometimes the example has the effect of induction," but remains an example nonetheless. Moreover, the fact that he deals with the "locus ab inductione" as an oratorical argument suggests that even induction can be traceable back to the oratorical inference of example. For all these reasons, Robortello concludes that induction and example never differ by form, but only by matter, and indeed Aristotle himself appears to make the point that there is induction whenever there is a universal conclusion. But this is misleading for Robortello, who avoids this ambiguity by distinguishing the two inferences only according to matter. Thus he suggests calling example every kind of inference that has to do with human actions, even if this inference has the form of an induction.

Yet Robortello has another argument up his sleeve which Aristotle himself would have had a hard time refuting. His aim is clearly to understand Aristotle better than Aristotle understood himself, and he claims that since every proof requires a universal, and since the example proves something, the example somehow must have something in common with the universal - precisely the case in which what the Stagirite called induction deals with human actions. Moreover, he adds, if induction is the mother of syllogism, collecting the particulars and transforming them into a universal, the example must be the father of the enthymeme.

Thus for Robortello the example has both matter and form. The former is constituted by human actions, whereas the latter can be twofold, either universal or particular. Induction, on the other hand, has a twofold matter, artificial and natural things, and only one general form. This is no doubt an interesting conception of both example and induction which is completely original and unique, finding no parallel in the following rhetorical and logical discussion. Example, in Robortello's view, is the very basic form of every kind of argumentation which 
can lead directly to the enthymeme, or indirectly to the induction in which syllogism is grounded.

In brief, for Robortello, the orator is faced primarily with an uneducated and vulgar audience, and deals with human actions through their proper argument, namely example. Rhetoric conceived as oratory has the aim of teaching people, but not every kind of knowledge: rather it teaches them only what they can really understand and use, namely what is helpful in making a right decision and performing an action..$^{28}$

The manuscript Donà dalle Rose 447 , folder $28,6 \mathrm{r}-\mathrm{v}$ also contains a handwritten scheme in Latin of Robortello's conception of the orator and his requirements. ${ }^{29}$ Whereas in the De rhetorica facultate Robortello examined the ancient conceptions of rhetoric, in the De artificio dicendi he distinguished the various kinds of discourse and emphasised the features of rhetorical discourse, and in Dell'oratore he dealt with the task of the orator and his arguments, in the scheme "Quae potissimum in oratore requirantur" he focused on the particular features of the orator and of its performance. Since the task of the orator is to popularise knowledge, it is first of all necessary to possess the science of the subject-matter under discussion, otherwise the oratorical discourse will be empty and useless. Robortello therefore stresses above all the fact that knowledge and teaching are the primary goals of the orator, not persuasion and deceiving. In order to achieve these goals, the orator must be able to find the right words and construct sentences effectively. Furthermore, the orator must have a profound knowledge of the inner passions of the soul and be able to entice them in order to arouse the interest of the audience. But since the orator aims to popularise knowledge, he must be able to speak also of subtleties in a very short, clear, but polished manner, in such a way that everyone can understand his discourse. He must possess a vast knowledge of historical examples or legal cases, and must perform appropriately, working on gestures, body movements, facial expressions, and the voice, adapting it to whichever situations may arise. In this way, the orator can speak on every topic, despite the fact that for the ancient Greeks, as Robortello points out, his role was confined mainly to disputes in trials. According to Robortello, however, not every person can be an

${ }^{28}$ Cf. J.M. Atwill, Rhetoric Reclaimed. Aristotle and the Liberal Arts Tradition (Ithaca: Cornell University Press, 1998), 196-201.

${ }^{29}$ The scheme is reproduced in the appendix. Cf. P.O. Kristeller, Iter Italicum. Iter Italicum. A Finding List of Uncatalogued or Incompletely Catalogued Humanistic Manuscripts of the Renaissance in Italian and other Libraries Volume 6. Italy III and alia Itinera IV (Leiden: Brill, 1991), 275. 
orator. An orator requires a particular natural wit in order to elaborate convincing arguments, a characteristic which cannot be developed through the teaching of the oratorical art and its precepts, which serves only to sharpen and amend innate powers of the mind.

\section{Conclusion}

To conclude this first fully-fledged investigation of Robortello's conception of rhetoric based on manuscripts and printed works, we can summarise his original perspective as follows. Besides historical examinations of ancient rhetoric, Robortello restricts rhetoric to the domain of oratory. Oratory has the purpose of popularising knowledge, that is to render even complex content more relevant to the ignorant and uneducated populace. In so doing, the orator must base his arguments on particulars, which are more easily understood than universals. For this reason, the orator employs the inference of example, which shows concretely the content of knowledge. Underlying this idea is the conception that knowledge must be available and accessible to all, thus everyone should be able to see with their own eyes and have a personal experience of what is being learned. This popularisation, however, affects only certain branches of the Renaissance system of knowledge, namely those that come under the umbrella of civic philosophy (ethics, politics, and economics). Sciences such as physics or metaphysics, which are based on universals and employ demonstrative syllogism, cannot be popularised. Eloquence, in this sense, must apply only in certain specific cases and to certain particular fields, and in fact appears to be concerned solely with moral philosophy. In order to make an oratorical and popular discourse, the orator must possess by nature a particular gift which is only partially the result of learning and doctrine. This is the reason why Robortello dislikes the schoolteacher of rhetoric and rhetorical textbooks, since eloquence is not something that can be completely taught, and at the same time demands considerable wisdom and erudition. Thus the orator, in Robortello's view, must be above all else a philosopher capable of disseminating the results of his research even among the common people. This becomes evident also in the emphasis placed upon the matter of knowledge in the distinction between example and induction, rather than the form of the inference. For all these reasons, oratory is a strategic tool, and Robortello has inaugurated a new era for rhetoric. 


\section{$\left[1^{R}\right]$ Dell'oratore ${ }^{30}$}

\section{Quesito primo}

$\mathrm{E}^{\mathrm{mo}}$ Sig risponderò al quesito primo che fu se ben mi ricordo, perché l'oratore usa lo entimema cosi imperfetto et non intiero come il sillogismo usato dal Dialectico, in questo modo. Omnes proditores sunt puniendi, ergo Aeschynes est puniendus. Ne vedo che alcuno Rhetore antico habbi fatto tal quesito, ovvero assegnato la ragione, onde più necessaria causa apparirà et V.S.E. havere mossa a farsi il quesito, et me al rispondere. Sarò pero breve riserbandomi a vestire in Latino questa disputazione più copiosamente.

Fundamento della mia risposta sarà questo. L'ORATORE ha da farsi con auditori rozzi, et ignoranti di scienze. Et questo disse anchora Arist ${ }^{\mathrm{e}}$ nel $\mathrm{p}^{\mathrm{mo}}$ della sua Rhet. ${ }^{\mathrm{ca}}$ non una volta ma più togliendo la similitudine dall'huomo che ha vista curta, ne vede molto da lungo, perché l'ignorante vede poco al pari del sciente, il quale specula da lungo ogni cosa con il suo intelletto per mezzo delli universali. Et l'ignorante a pena vede il particolare, perché non è usato ad abstragere speculando l'universale dalli particolari, come il sciente, perché tutte le scienze sono fatte di termini universali. Onde s'imparano anticamente prima da i putti le mathematice per assuefare l'intelletto a tal specule, la quale causa dalli particolari sensati l'universale. Et invero è più difficile da prendere l'universale, che il particolare, onde ben habbiamo detto che l'universale è apreso solamente dal sciente, et il particolare dal'ignorante, et rozzo, ovvero popolar huomo. Il secondo fondamento adunca sarà che l'auditore dell'oratore per essere rozzo, et populare apprende solamente il particolare, ma non l'universale. Più l'oratore versa circa le attioni particolari di questo o quello, ne tratta questione alcuna universale. Di qui nasce che l'oratore mette la sua materia nella forma del sillogismo detto volgarmente nelle scuole DARIJ, ma non mai nella forma del sillogismo detto nelle scuola Barbara, et la ragione è, perché il sillogismo DARIJ ha una universale proposizione, l'altra particolare, et similmente la conclusione particolare, ma il sillogismo Barbara è tutto

\footnotetext{
${ }^{30} \mathrm{BMCVe}$, Donà dalle Rose 447, folder 28 (1566-1567 ca.). Folder 28 contains: 1 ) Dell'oratore, ff. 1r-3v (with one additional unbounded leaf); 2) Del translatare d'una lingua in l'altra, ff. 4r-5v; 3) Quae potissimum in oratore requirantur, ff. 6r-v; 4) Della figura delle parole, ff. $7 \mathrm{r}-\mathrm{v}$. The transcript of BMCVe, Donà dalle Rose 447, folder 28, ff. $1 \mathrm{r}-3 \mathrm{v}$ is an exact copy of the text. The present edition - strictly diplomatic - preserves original spelling as well as capitalization, italicization, lineation, and punctuation, even when erroneous, reproducing all the orthographic information provided by the manuscript.
} 
composto d'universali, ${ }^{31}$ però non è popolaresco, ne oratorio, perché non saria appreso per rispetto delli universali. Hora mi dira qualchuno, in questo enthimema omnes proditores sunt puniendi et cet. se l'auditore dell'oratore è rozzo, come apprendera questo universal posto nell'enthimema. Rispondo in doi modi, il p. ${ }^{\text {mo }}$ che per rispetto della seconda propositione, la quale è particolare, et la conclusione ancora similmente, facilmente intende quella universale, ma quando anchora la seconda propositione, et la conclusione fussero universali, durarebbe fatica l'auditore popularesco a discorere per tanti universali, come si diria d'un $\left[1^{\mathrm{V}}\right]$ vecchio debole per fare un salto solo lo farà, ma farne do o tre uno doppo l'altro non potrà. Nell'altro modo rispondo che si suole lassare l'universale prima nell'enthimema, et dire cosi Aeschynes est proditor, ergo est puniendus, et cosi non essendo niente d'universale facilmente apprende il tutto. Ma posto che l'universale di metti in ogni modo, dico che è differentia tra universale, et universale, et l'universale oratorio è più facile d'apprendere che non è l'universale physico, o d'altra scienza, et la ragione è perché l'universale oratorio è di materia di attioni communi, et quotidiane note a tutti. Ma l'universale physico, et scientifico è di materia lontana da tali attioni, ne è cosi noto al popolaresco, come chiaramente si puo vedere, anchora ch'io non metta esempij. Et che la materia oratoria sii tale, lo disse Arist ${ }^{\mathrm{e}}$ nel p. ${ }^{\text {mo }}$ della sua Rhet. ${ }^{\text {ca }}$ luogo advertito da pochi ma bellissimo che la materia dell'oratore è quella che consta di cose, le quali non sono ridutte a methodo di scienza, non arte, o scritte di gia, o che per l'avenire si possin scrivere, perché tutto è uno. Adunque, se cosi è non durerà fatica in discorrere per tali universali l'auditore dell'oratore anchora che rozzo et popolaresco. Anchora uno dubitando mi dirà, tu hai detto che è proprio dell'enthimema lassare una delle propositioni per la causa detta, ma io vedo che ancora il scientifico non mai mette il suo sillogismo composto d'universali intero nel suo parlare. A questo rispondo che si, et si fa con ottima ragione, perché il scientifico parla con auditori eruditi et atti ad apprendere ogni universale. Et questo auditore erudito del scientifico dire si puo populare nel suo genere, come l'auditore dell'orator nel suo. Et si come la materia delle attioni comuni, et quotidiane è nota all'auditore del scientifico, et pero intendendo non si ricerca forma intera del sillogismo, di qui nasce che ne i libri de coelo, della physica, et altri, non mai quasi si trovano sillogismi

\footnotetext{
${ }^{31} \mathrm{~A}$ me pare, che non per questo, che il sillogismo in barbara è tutto di universali, l'oratore non l'usa, ma ben per questo, perché non gli è necessario usarlo, et a cio è astretto, peroche trattando per il più cose particolari l'oratore, conviene ancho che le proposi: tiene del suo sillogismo andino a particolari, ne pero anchora mai non l'usa il sillogismo in barbara l'oratore, ma ben alcune volte come, quando diggreditur in locum commune che è come questione universale.
} 
interi et ordinati a punto secondo la sua regola, perché il parlatore demonstrativo, et cosi anchora l'oratore imitano il parlare commune, nel quale non si vede tal forma intiera, ma hora si lascia la conclusione, hora la $\mathrm{p}^{\mathrm{ma}}$ propositione, hora la seconda, et si perverti l'ordine anchora di esse, hora ritornando a quella di prima, se alcuno dubitando dicesse. Io vorei sapere perché l'enthimema è in la forma darij, rispondo, perché nasce dall'esempio, il quale è particolare, cosi, Aeschyne imbasciatore si lasciò corrompere, perché Alcibiade, Adunque tutti li imbasciatori si lasciano corrompere, questa universale $\left[2^{\mathrm{r}}\right]$ si è tirata da quelli particolari esempij. Il sillogismo nasce dall'induttione, cosi, questo bu, et quello, et quello rumina, ad anco tutti li boi, questo bue ha corna et tutti, questa capra, Adonca tutti quelli animali quadrupedi, che hanno corni, ruminano. Ecco provato ch'io ho questo per l'induttione, io faccio subito il sillogismo in Barbara, il quale è scientifico in tale modo:

Omne animal habens cornus ruminatur,

Omnis bos habet cornuo

Ergo omnis bos ruminatur.

\section{Questio $2^{\circ}$}

\section{Quale differenza sii tra l'induttione, et l'esempio}

Lasciando da banda molte et molte opinioni dirò brevemente quello ch'io stimo esser vero in tal materia, nella quale doppo molto pensamento mi sono risoluto, non mosso da autorità di alcuno scrittore il quale cosi a punto habbi scritto, ma indutto dalla ragione la quale in tai quesiti debba prevalere all'authorita, et dirò prima l'origine di tal quesito. Questo quesito non è dubio che nasca dalla somiglianza della forma dell'argumentare, che è tra l'induttione et l'esempio alle volte, perché dicendo alcuno cosi, Pisistrato dimandò la guardia delli soldati, quando era in magistrato, et occupò la liberta. Timoleonte dimando la guardia, et occupò la liberta. Euridemo, Sostrato etc. Adunque tutti quelli che occupano la liberta, la occupano per quel mezzo. Qui vedo l'Historia, et mi pare esempio. All'incontro io vedo molti particolari, onde si raccoglie l'universale, et mi pare induttione, ne mi so risolvere come chiamare debba tal modo di argumentare. Hora la mia openione è questa, che la differenza essenziale sia l'esempio, et l'induttione si piglia dalla materia, perché la materia dell'essempio è di attioni publice quali si contengano nelle historie overo anchora di attioni private d'huomini. La materia della induttione è di cose naturali, or artificiali, ne mai altrimenti osserverà alcuno ne metto per hora esempij perché la cosa da se è chiarissima. La forma non li fa differenti, perché alle volte l'esempio sottentra nella forma dell'induttione, come di sopra apparisce, 
ma non all'incontro mai l'induttione entro in forma esemplare, et accio questo meglio s'intendi io dicchiaro brevemente. L'esempio si fa da uno

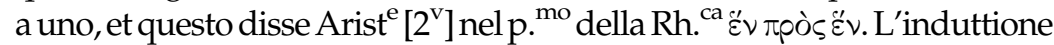
si fa da molti particolari a uno universale il quale si raccoglie da quelli come per conclusione. [Regola $1^{a}$ ] Hora ogni volta che uno essempio si deduce da uno a uno, non è dubio alcuno, che è esempio, purche sij di materia sopra detto. [Regola $2^{a}$ ] Accade alle volte che l'esempio si deduce da doi et tre et quattro a uno pur pero particolare, per molti particolari a uno universale et in tal caso quelli doi tre et quattro hanno forza d'uno raddoppio, ovvero uno per uno si debbe dedurre alla conclusione, onde apparirà il medesimo che nella $\mathrm{p}^{\mathrm{ma}}$ regola habbiamo detto. [Regola $3^{\mathrm{a}}$ ] Accade ancora chel'essempio si deduce per molti particolari a uno universale, et allhora sottentra nella forma della induttione. Ne debba alcuno per questo pensare che ij induttione, perché la materia è di cosi fatte, cio è di attioni humane, la quale è principalmente da l'essere all'essempio. Nota se qualcuno non approvasse, saria forzato dire che la materia della induttione non è solamente di cose naturali, et artificiali, ma anchora di attioni humane, ma la materia dell'esempio è solamente di attioni humana. Se questa opinione è probabile o non, ogniuno giudichi. Si potrebbe accettando questa openione dirsi anchora che nella forma dell'esempio, cheè di uno a uno sottentra alli volte la materia di cosenaturali et artificiali, ut rosa, sic virgo, ut leo sic miles et cet. ma all'hora perde il nome di esempio et piglia il nome di similitudine, a tale che sariano tre forme di argumenti anchora che la similtitudine non sia argumento.

1. essempio

2. induttione

3. similitudine

A dire nella $3^{\mathrm{a}}$ regola, che l'esempio sottentra in forma d'induttione mi muove Arist ${ }^{\mathrm{e}}$, al quale porto quella riverenza maggiore che si può. Egli nel $2^{\circ}$ lib $^{\circ}$ della Rhet. ${ }^{\text {ca }}$ dove tratta delli luoghi de i argumenti oratorij, mette tra gli altri anchora questo "locus ab inductione. Parij honore affecerunt Archilochum, Chij Homerum, Ergo omnes sapientes honorantur." Questo secondo la mia distintione di sopra $\left[3^{r}\right]$ si doveria chiamare esempio, perché ha la materia di cose fatte da huomini. Ma Arist ${ }^{\mathrm{e}}$ la chiama induttione, et non essempio, et quello che è da notare, fra tanti luoghi d'argomenti nel $2^{\circ}$ libro non nomina mai l'essempio. Disse adonca egli, che exemplum aliquando habet vim inductionis, et questa è la sua openione. Adunque osservando la materia, noi distingueremo uno dall'altro. Pareva ad Arist ${ }^{\mathrm{e}}$ che lo essempio non dovesse havere conclusione universale, come la induttione, et pero ogni volta che si fa la conclusione universale anchora che materia sij esemplare Arist ${ }^{\mathrm{e}}$ gli da il nome di induttione. Io per levarmi questa ambiguità, havendo 
rispetto alla materia essemplare che è di cose fatte da huomini, cio è ex rebus gestis, non considerando più la forma, lo chiamano essempio, achora che havesti forma d'induttione. Ne voglio contrastare con Arist ${ }^{\mathrm{e}}$ ma forse ch'io lo vincerei con questa ragione, che sicome il sillogismo, enthimema, et induttione partecipane dell'universale o avanti o doppo, cosi è necessario che l'esempio participi anchora, perché senza universale niente si prova, ne si raccoglie. Tanto più perché pare che la induttione sij come una madre del sillogismo. Per il simile adonca debbe l'essempio essere come un padre dell'enthimema. Questo dico perché da quella universale che raccogliere in conclusione sua l'induttione si genera il sillogismo et similmente da quella universale che raccoglierà l'essempio si genera l'enthimema. Ma se l'enthimema anchora lui nasce dall'induttione, che accade tanto spesso havere nominato l'essempio et contrapurlo all'induttione nella Rhetorica. Queste sono le mie ragioni per hora, et molte altre sariano a convincere Arist. ${ }^{\mathrm{e}}$ che doveva nel $2^{\circ}$ della Rhet. ${ }^{\text {ca }}$ chiamare quell'argumento essempio, et non induttione, riguardando la materia et non la forma, perché alle volte la forma è la medesima dell'essempio, quale è quella della induttione. Et più propria forma dell'essempio a mio giuditio è quella che coglie l'universale da molti particolari, che quella, la quale raccoglie il particolare et uno da uno particolare. La conclusione dunque sij questa. L'esempio ha materia et forma. Materia, rerum gestarum $\left[3^{\mathrm{v}}\right]$ $a b$ hominibus. La forma è di doi sorti, una d'uno a uno l'altra di più particolari a uno universale, et in questo è compagno della induttione.

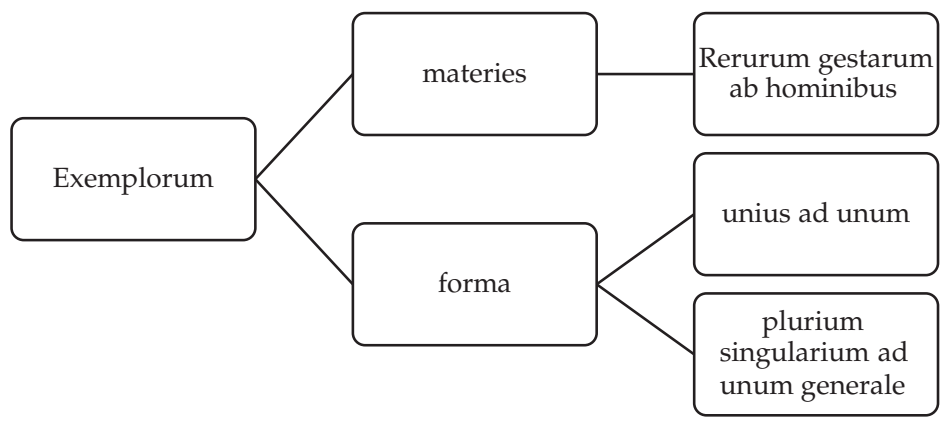

Hora diciamo in conclusione anchora della induttione.

La induttione ha anchora lei materia et forma. Materia di cose naturali et artificiali. Forma di più particolari a uno universale.

Quella sorte d'induttione Platonica, che va da diversi particolari a uno diverso particolare, a me pare piuttosto similitudine, che altro. Ma diremo di questa un'altra volta a lungo. Hora basti. Et io a V.S. Cl. ${ }^{\mathrm{ma}} \mathrm{mi}$ raccomando.

Di V.S. Cl.ma servitore il Robortello 


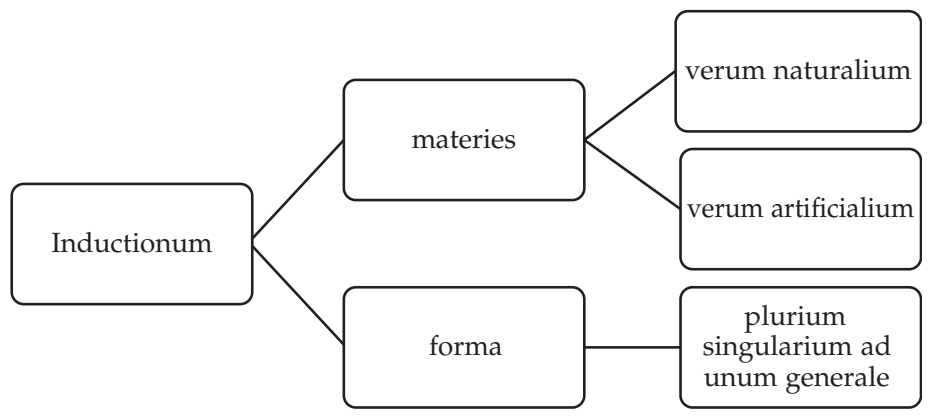

\section{$\left[6^{\mathrm{r}}\right]$ Quae potissimum in oratore requirantur}

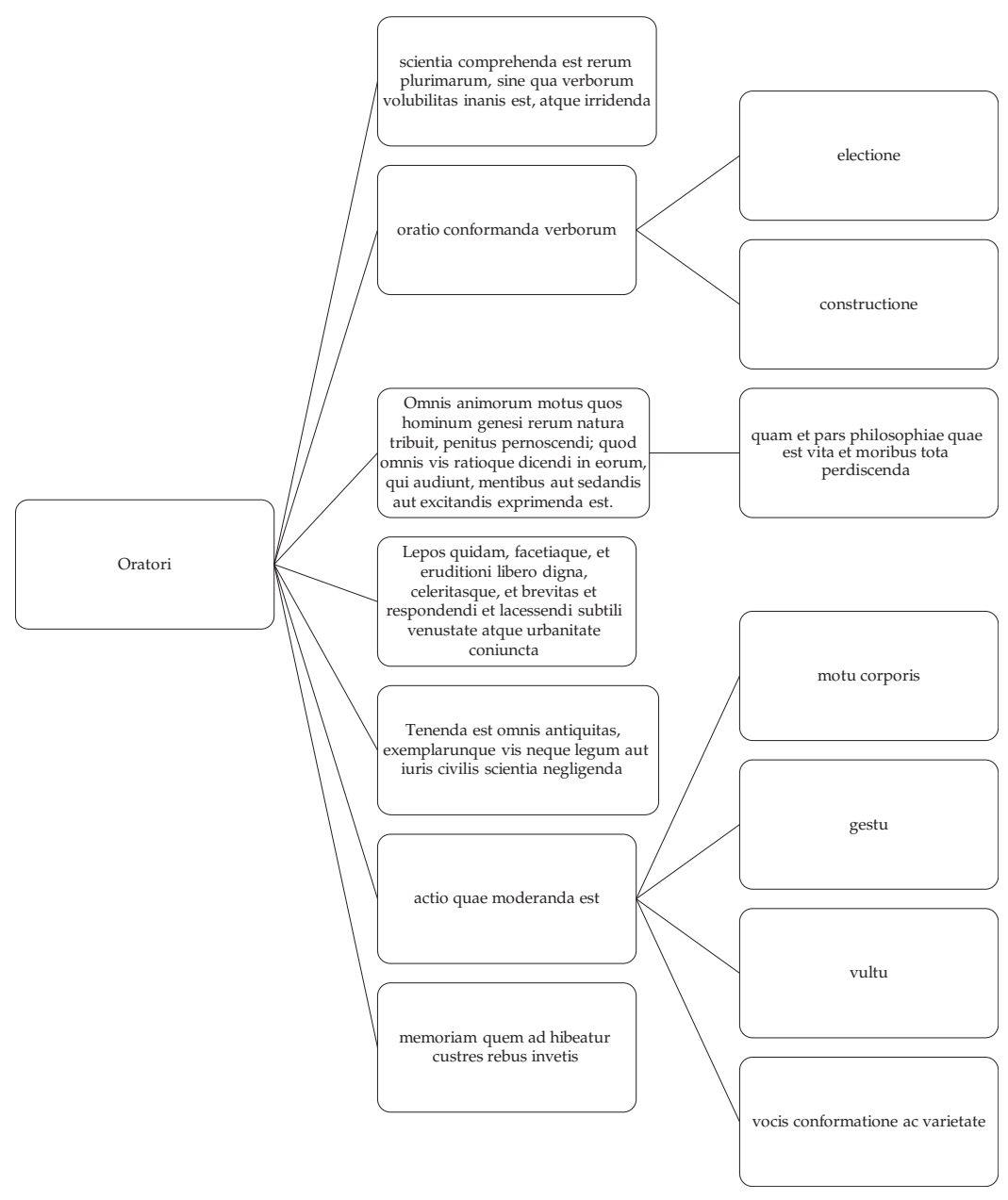


Vis oratoris professioque ipsa bene dicendi hoc suscipere ac polliceri videtur, ut omni de re, quicunque sit proposita, ab eo ornati copioseque dicatur.

Sed Graeci aiunt, oratorem versari in rebus civilibus, hoc est in forensi disceptatione iudiciorum, ac deliberationum. $\left[6^{\mathrm{V}}\right]$

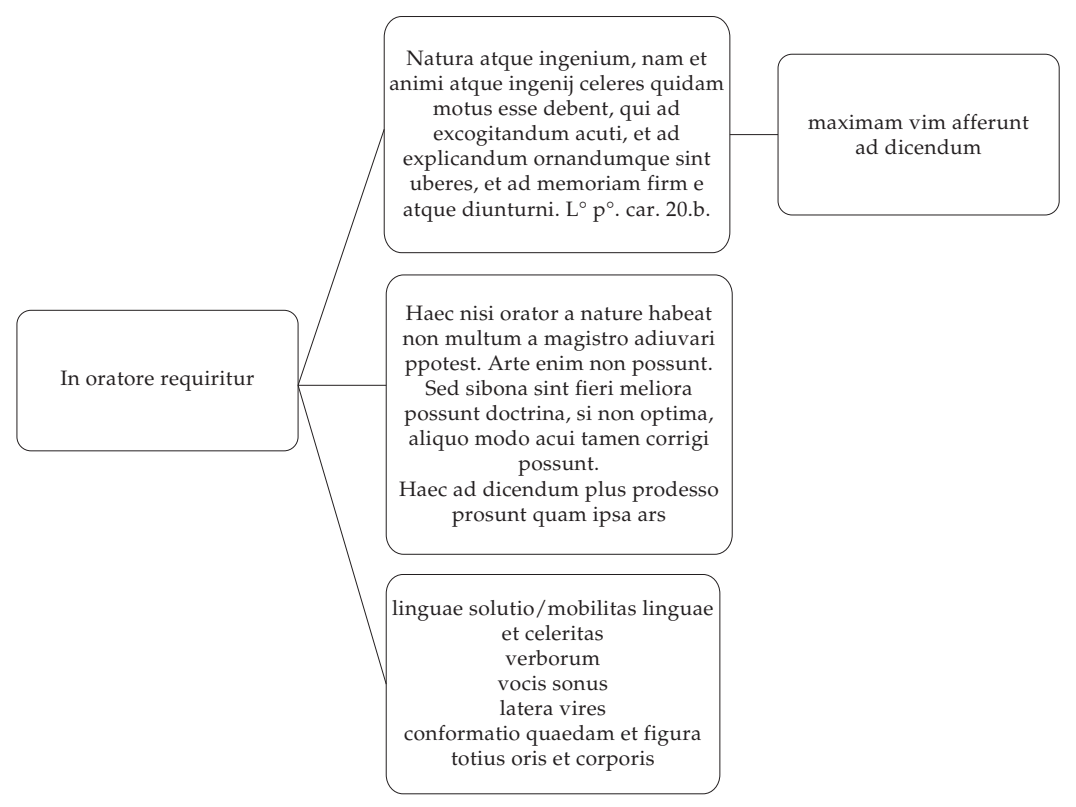

